\title{
Mizahın Gücü: Mizahın İș Talepleri Karşısında Olumsuz Duyuşsal İyi Oluş Algısını Azaltıcı Etkisi
}

\section{The Power of Humor: Its Buffering Effect on Negative Job-related Affective Well-being against Job Demands}

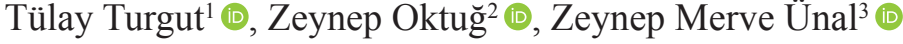

1Prof. Dr., Marmara Üniversitesi, İşletme Fakültesi, İşletme Bölümü (İngilizce), İstanbul, Türkiye

${ }^{2}$ Doç. Dr., İstanbul Kültür Üniversitesi, Fen Edebiyat Fakültesi, Psikoloji Bölümü, İstanbul, Türkiye

${ }^{3}$ Dr. Öğr. Üyesi, İstanbul Gelişim Üniversitesi, İktisadi İdari ve Sosyal Bilimler Fakültesi, İşletme Bölümü (İngilizce), İstanbul, Türkiye

ORCID: T.T. 0000-0002-6022-1652;

Z.O. 0000-0002-8021-9074;

Z.M.Ü. 0000-0003-4927-3117

\section{Sorumlu yazar/Corresponding author:} Tülay Turgut,

Marmara Üniversitesi, İşletme Fakültesi, İşletme Bölümü (İngilizce), İstanbul, Türkiye E-posta/E-mail: tturgut@marmara.edu.tr

Başvuru/Submitted: 11.01.2019 Revizyon Talebi/Revision Requested: 23.03.2019

Son Revizyon/Last Revision Received: 10.07.2019

Kabul/Accepted: 19.07.2019

Online Yayın/Published Online: 18.10.2019

Atıf/Citation: Turgut, T., Oktug, Z., Unal, Z. M. (2019). Mizahın gücü: Mizahın iş talepleri karşısında olumsuz duyuşsal iyi oluş algısını azaltıcı etkisi. Psikoloji Çalışmaları - Studies in Psychology, 39(2): 267-291.

https://doi.org/10.26650/SP2019-0004

\begin{abstract}
ÖZ
$\mathrm{Bu}$ çalışmanın amacı, iş yerinde mizah yoluyla başa çıkma eğiliminin iş talepleri ile çalışanların işe ilişkin olumsuz duyuşsal iyi oluş algıları arasındaki ilişkideki biçimlendirici rolünü incelemektir. Artan rekabetin ve güçleşen iş koşullarının, bireyleri gün geçtikçe karmaşıklaşan bir çalışma ortamı ile karşı karşıya bıraktığ 1 görülmektedir. Bu bağlamda, çalışanın olumsuz duygularında azalma sağlayabilecek her unsurun dikkatle incelenmesinin gerekliliği göz önüne alınmış ve iş taleplerindeki artışla birlikte çoğalacağı düşünülen işe ilişkin olumsuz duyuşsal iyi oluş algılarının mizah yoluyla azaltılabileceği öngörüsünden hareketle araştırmanın modeli oluşturulmuştur. Araştırmanın örneklemini Türkiye'nin farklı şehirlerinde eğitim ve sağlık sektörlerinde çalışmakta olan 319 katılımcı oluşturmuştur. Hiyerarşik regresyon ve basit eğim analizleri, iş yerinde mizah yoluyla başa çıkma eğilimi arttıkça iş talepleri ile olumsuz duyuşsal iyi oluş algısı arasındaki pozitif ilişkinin zayıfladığını ortaya koymuştur. İş talebi yüksek ve mizah yoluyla başa çıkma eğilimi düşük olan çalışanların, iş talebi yüksek ancak mizah yoluyla başa çıkma eğilimi yüksek olan çalışanlara nazaran, olumsuz duyuşsal iyi oluş algıları daha fazladır. Araştırma bulguları, mizah yoluyla başa çıkma eğilimi zayıf olan kişilerin, mizah yoluyla başa çıkma eğilimi güçlü olan kişilere nazaran yüksek iş talepleri karşısındaki olumsuz duyuşsal iyi oluş algıları açısından daha dezavantajlı durumda olabileceğini ortaya koymuştur. $\mathrm{Bu}$ bulgular, iş yerinde mizah yoluyla başa çıkma becerilerinin, yalnızca çalışanın sağlığına olumlu katkı sağlama açısından değil, iş taleplerinin karşılanması açısından da önem arz ettiğini göstermiştir.
\end{abstract}

Anahtar Kelimeler: İş yerinde mizah, iş talepleri, işe ilişkin duyuşsal iyi oluş algis1 


\section{ABSTRACT}

The aim of this study is to investigate the moderating role of occupational humorous coping on the relationship between job demands and negative job-related affective well-being perception. Because of the increasing competition and difficult conditions, individuals encounter an increasingly complex working environment. In this context, every element that may cause a reduction in the employees' negative feelings should be taken into consideration. The model of the study is established in light of the foresight that occupational humor can reduce the negative job-related affective well-being perception which is expected to increase depending on the job demands. Employees working in the education and health sectors in Turkey $(N=319)$ participated in the study. Hierarchical regression and simple slope analysis revealed that as the occupational humorous coping tendency increases, the positive relationship between job demands and negative job-related affective well-being perception decreases. Employees whose job demands are high and whose tendencies for occupational humorous coping are low, have higher negative job-related affective well-being perception levels than the employees whose job demands and whose tendencies for occupational humorous coping are high. The findings of the study showed that in terms of negative job-related affective well-being perception in the face of high job demands, the employees with a weak tendency for occupational humorous coping are at a disadvantage in comparison to the employees with a stronger tendency for occupational humorous coping. These findings put forward that occupational humorous coping is an important skill not only in terms of contributing positively to the health of the employee, but also in terms of meeting job demands.

Keywords: Humor in workplace, job demands, job-related affective well-being

\section{EXTENDED ABSTRACT}

In recent years, different methods for controlling the emotional effects caused by the demands in work place began to attract attention. The job demands-resources model is a functional model for assessing the well-being of the employee (Demerouti \& Bakker, 2011). Schaufeli and Bakker (2004), pointed out that it should be more effective to decrease the job demands rather than to increase job resources. From this point of view, it is considered that it is important to prevent a negative job-related affective well-being perception in order to enhance the factors related to quality of work life. Humor is an important phenomenon that can have a positive effect on the individual's perception of well-being. It may decrease the negative job-related affective well-being perception. Based on this idea, this study aims to investigate the moderating role of occupational humorous coping on the relationship between job demands and a negative perception job-related affective wellbeing.

\section{Method}

The sample of this research constitutes 319 employees from various cities of Turkey working in the education and health sectors. For measuring job demands, a scale (Xanthopoulou, Bakker, Demerouti, \& Schaufeli, 2007) with four sub-scales including workload (4 items), emotional demands (6 items), emotional dissonance (5 items) and 
organizational changes ( 7 items); for measuring the negative job-related affective wellbeing perception, 10 items measuring negative job-related affective well-being perception of the Job-related Affective Well-being Scale (Van Katwyk, Fox, Spector, \& Kelloway, 2000) and for measuring occupational humorous coping, the Occupational Humorous Coping Scale (23 items), which was developed by Doosje, De Goede, Van Doornen and Goldstein (2010), was used.

\section{Results}

For testing the hypotheses, hierarchical regression and simple slope analyses were conducted. According to the hierarchical regression results, in the first model, job demands have a positive effect on the negative job-related affective well-being perception ( $B=0.45$, $\left.S H=0.06 ; R^{2}=.19, p<.001\right)$. In the second model, when occupational humorous coping was added to the equation, the explanatory strength of the model increased $\left(\Delta R^{2}=.18, p<.001\right)$ and it was revealed that occupational humorous coping has a negative effect on the negative job-related affective well-being perception $(B=-0.44, S H=0.05)$. In the third model, the interaction of job demands and occupational humorous coping has an effect ( $B$ $=-0.15, S H=0.05)$ on the negative job-related affective well-being perception $\left(\Delta R^{2}=.02, p<\right.$ $.001)$. Occupational humorous coping has a moderating effect on the relationship between job demands and the negative job-related affective well-being perception. Thereafter, simple slope analysis and a test for difference in simple slopes revealed that high occupational humorous coping weakens the positive relationship between job demands and the negative job-related affective well-being perception (for high occupational humorous coping: $b=.24, t=3.816, p<.001$; for low occupational humorous coping: $b=$ $.41, t=9.171, p<.001$; for difference in simple slopes $t(604)=2.096, p<.05)$. According to this, as the occupational humorous coping tendency increases, the positive relationship between job demands and the negative job-related affective well-being perception decreases.

\section{Discussion}

The results of this study showed that employees who have a low ability of occupational humorous coping are at a disadvantage when compared to employees who have a high ability of occupational humorous coping in the context of a negative job-related affective well-being perception against job demands. According to this, it can be said that the occupational humorous coping skills are not only important for the health of employees, but also important for responding to job demands. People are more sensitive to negative stimuli than to positive stimuli (Garcia, Rosenberg, Erlandsson, \& Siddiqui, 2010), and the 
increase in negative feelings in the workplace lead to increasing counterproductive behavior (Fox, Spector, \& Miles, 2001). In this context, this study examined the negative jobrelated affective well-being perception. Turkey is a high power distance country (Kabasakal \& Dastmalchian, 2001), which means that the status differences in organizations are important. It is thought that high power distance can be a restrictive factor for using humor in the workplace. From this point of view, there can be a greater need for an encouraging organizational climate. The negative and positive affective well-being perceptions can be examined separately. The decrease in negative affective well-being perception does not mean an increase in positive affective well-being perception. Therefore, in future studies, it will be useful to examine the positive job-related affective well-being perception in relation to job demands and also the effects of occupational humorous coping in the context of these relationships. 
Son yıllarda iş yaşamındaki koşulların giderek güçleşmesi, araştırmacıların ilgisini, çalışanların psikolojik açıdan iyi oluşlarının sağlanmasına yöneltmektedir. Bu çerçevede, pozitif psikoloji alanındaki çalışmalar daha fazla dikkat çekmeye başlamış; olumsuz yanların iyileştirilmesi yönündeki çaba, olumlu özellikleri geliştirmeye doğru yönlenmiştir. İş yaşamında bireylerin karşısına çıkan taleplerin yarattığı duygusal etkileri kontrol edebilmek amacıyla farklı yöntemlerin araştırılmaya başlanması, günümüzün zorlayıcı çalışma koşullarının doğal bir sonucu olarak görülebilmektedir.

İş ortamında oluşan talepler, çalışan tarafından bilişsel olarak değerlendirilmekte, taleplerle başa çıkabilecek kaynaklara sahip olunmadığına kanaat getirilmesi durumunda, çalışanın stres düzeyi artmaktadır (Lazarus ve Folkman, 1984). İş talepleri-kaynakları modeline göre ise (Demerouti, Bakker, Nachreiner ve Schaufeli, 2001), taleplerin çalışanın enerjisini zorlayıp tükettiği ve çalışanın kaynakları aracılığıyla taleplerle başa çıkarak motive olduğu iki yönlü bir süreç işlemektedir. İş talepleri-kaynakları modeli, çalışanın işe ilişkin iyi oluşunun değerlendirilmesinde işlevsel bir model olarak görülmektedir (Demerouti ve Bakker, 2011). Schaufeli ve Bakker (2004), iş talepleri-kaynakları modeli aracılığıyla, tükenmişliği ve çalışmaya tutkunluğu irdeledikleri araştırmalarında, iş kaynaklarının çalışmaya tutkunluğu artırdığını, ancak tükenmişlik üzerindeki etkisinin düşük olduğunu belirtmişlerdir. Bu nedenle, iş kaynaklarını artırmaktansa, iş taleplerini azaltmanın daha işlevsel olabileceği ileri sürülmüştür. Bu noktadan hareketle, iş taleplerinin olumsuz etkilerini azaltabilecek unsurlar üzerinde çalışılması yararlı görünmekte ve bu bağlamda mizah yoluyla başa çıkmanın olumsuz etkileri azaltma gücünün test edilmesi önem kazanmaktadır. İş talepleri-kaynakları modelini inceleyen çalışmalarında Xanthopoulou, Bakker, Demerouti ve Schaufeli (2007), daha fazla bireysel kaynağa sahip olan çalışanların iş taleplerinin yarattığı olumsuz etkilere karşı daha dayanıklı olduklarını ortaya koymuşlar ve çalışanların bireysel kaynaklarının güçlendirilmesine yönelik çalışmaların yapılmasını önermişlerdir. İş yerinde mizah yoluyla başa çıkmanın iş taleplerinin yarattığ 1 olumsuz etiklerle başa çıkmadaki rolü, bireysel kaynakları güçlendirmede dikkate alınması gereken bir unsurdur. Bu çalışmanın, iş yerinde mizah yoluyla başa çıkmayı işlevsel bir bireysel kaynak olarak inceleyerek, alan yazına katkı sağlaması hedeflenmektedir.

Yaşamın önemli bir bölümünün iş ortamında geçmesi, bireyin iş yaşamındaki iyi oluşuna dair algılarının da önem kazanmasını ve incelenmesini beraberinde getirmiştir. İşe ilişkin duyuşsal iyi oluş algısı (job-related affective well-being perception), çalışanın 
genel anlamda işiyle ilgili olumlu ve olumsuz duygularının belirlenmesini kapsamaktadır (Van Katwyk, Fox, Spector ve Kelloway, 2000). Çalışanların duygu durumu ile ilgili çalışmaların bir kısmı iş yerindeki koşulların duygularla olan ilişkisini incelerken, bir kısmı çalışanların duygularının örgütteki davranışlarıyla ilişkisini vurgulamaktadır (Warr, Bindl, Parker ve Inceoglu, 2014). Weiss ve Cropanzano (1996) Duygusal Olaylar Teorisi kapsamında duyguların iş yerindeki davranışlarla olan ilişkisini ortaya koymuşlar, iş yerinde gerçekleşen olayların çalışanın duygulanımı üzerindeki etkisi ile duygulanımın tutumlar ve bu tutumlara bağlı davranışlar üzerindeki etkisinin önemini vurgulamışlardır. Bu bağlamda, çalışanların işle ilgili olumlu ya da olumsuz duygularını içeren işe ilişkin duyuşsal iyi oluş algısı kavramı örgütsel sonuçlar açısından önem arz etmektedir. Olumsuz duyguların tepki, süre ve bilişsel etkiler bakımından olumlu duygulardan daha güçlü olduğu görülmektedir (Larsen, 2009). Bu bağlamda, olumsuz duyguların örgütsel sonuçlar üzerindeki etkisinin olumlu duyguların etkisinden daha güçlü olduğu düşünülmektedir. Bu noktadan hareketle, duyuşsal iyi oluş algısının olumsuz boyutunun irdelenmesi önemli görülmüş ve bu çalışma kapsamında çalışanların olumsuz duyuşsal iyi oluş algıları ele alınmıştır.

Bireyin iyi oluş algısı üzerinde olumlu yönde etki yaratabilecek olgulardan biri mizah olarak görülmektedir (Ruch ve Carrell, 1998). Mizahın, iyimserlik düzeyiyle pozitif yönde ilişkilerinin yanı sıra (Crawford ve Caltabiano, 2011), durumluk ve sürekli neşeli olma haliyle de ilişkili olduğu belirtilmektedir (Falkenberg, Buchkremer, Bartels ve Wild, 2011). Bu bağlamda, mizahın, bireyin iş yerindeki duyuşsal iyi oluş algısıyla iliş̧kili olabileceği; iş koşulları sebebiyle gelişebilecek olumsuz duyuşsal iyi oluş algısını negatif yönde etkileyebileceği düşünülmektedir. Bu fikirden hareketle, bu çalışma kapsamında, iş talepleri ile olumsuz duyuşsal iyi oluş algısı arasındaki ilişkide, iş yerinde mizah yoluyla başa çıkmanın biçimlendirici rolü incelenmiştir.

\section{İş Talepleri ve Duyuşsal İyi Oluş Algısı}

Herhangi bir iş ele alındığında, o iş için, iş talepleri ve iş kaynakları olmak üzere, iki temel unsur söz konusu olmakta; iş talepleri, yerine getirilmesi gerekenleri vurgularken, iş kaynakları, iş taleplerini karşılamak ve işi amacına ulaştırabilmek için gerekli fiziksel ve psikolojik kaynakları belirtmektedir (Schaufeli ve Bakker, 2004). İş talepleri, iş yükünün yanı sıra, duygusal, bilişsel ve fiziksel talepleri de kapsamaktadır (Bakker ve Demerouti, 2008). Demerouti ve arkadaşları (2001) tarafindan oluşturulan, Schaufeli ve Bakker (2004) tarafından geliştirilen iş-talepleri kaynakları modeli, daha sonra Xantho- 
poulou ve arkadaşları (2007) tarafından genişletilmiş ve iş talepleri; iş yükü, duygusal talepler, duygusal uyumsuzluk ve örgütsel değişiklikler olmak üzere 4 faktör kapsamında değerlendirilerek tanımlanmıştır. İş yükü, rutin çalışma saatleri içerisinde yetiştirilmesi mümkün olmayan işler sebebiyle, çalışan üzerinde oluşan baskıyı işaret etmektedir (Genina, Haines IIIa, Pelletierb, Rousseaua ve Marchanda, 2016). Çalışma ortamında farklı biçimlerde ortaya çıkabilen duygusal talepler, duyguların işin bir parçası olarak sunulmasını içermekte ve bu durum, çalışanın duygularını zor koşullarda dahi yönetebilmesi gerekliliğini ortaya çıkarmaktadır (Rafaeli ve Sutton, 1987). Hochschild (1983), duygusal emek kuramında, çalışanların hangi durumlarda hangi duyguları sergileyeceklerinin örgüt tarafından belirlendiğini ve belirlenen bu kurallar çerçevesinde kalmanın çalışan için zorlayıcı olabileceğini ortaya koymuştur. Çalışma ortamının talep ettiği duygular ile çalışanın doğal eğilimiyle sergileyebildiği duygular arasında tutarsızlık olduğu takdirde, duygusal uyumsuzluk ortaya çıkmakta ve bu durum çalışanın iyi oluşunu olumsuz yönde etkilemektedir (Diefendorff, Greguras ve Fleenor, 2016). İş talepleri kapsamında incelenen örgütsel değişiklikler ise, örgütün herhangi bir kademesinde, herhangi bir hızda ya da derecede meydana gelebilmekte, çalışanda bir takım bilişsel, duygusal, davranışsal tepkiler oluşturmakta, bu tepkiler bağlamında çalışanın değişime direnci ya da desteği şekillenmektedir (Oreg, Bartunek, Lee ve Do, 2018).

İyi oluş kavramı araştırmacılar tarafından değişik yönlerden ele alınmış ve genel olarak üç farklı çerçevede açıklanmıştır (Diener, 1984). Birincisinde, iyi oluş, bireyin yaşadığı ortamda, kültürde ve zamanda, ideal olarak tanımlayabileceği öğelerle şekillenmektedir. İkincisinde, bireyin kendi yaşam kalitesine dair değerlendirmeleriyle ortaya çıkan yaşam doyumu vurgulanmaktadır. Üçüncüsünde ise iyi oluş, genel anlamda, olumlu duyguların olumsuz duygulardan daha ağır basması durumu olarak kabul görmüştür. Daha sonra Diener (1994), öznel iyi oluşu, yaşam doyumu, hoşnutluk veren duyguların uzun süreli varlığı ve hoşnutsuzluk veren duyguların yokluğu olarak tanımlamıştır. Yaşam doyumu, bireyin yaşamı ile ilgili genel bilişsel yargılarını kapsarken (Emmons ve Diener, 1985), olumlu duyguların varlığı ve olumsuz duyguların yokluğu, duyuşsal iyi oluşa işaret etmektedir (Pavot, Diener, Colvin ve Sandvik, 1991). Van Katwyk ve arkadaşları (2000) ise, bireylerin işe ilişkin duyuşsal iyi oluş algılarının dört boyutlu bir model ile ölçülebileceğini öne sürmüşlerdir (Bkz. Şekil 1). Modele göre, hoşnutluk ve uyarılmışlık düzlemlerinin kesişimleriyle, çalışanın işe ilişkin duyuşsal iyi oluş algısının olumlu ya da olumsuz yönü belirlenmektedir. Yüksek hoşnutluk ve yük- 
sek uyarılmışlık ile yüksek hoşnutluk ve düşük uyarılmışlık işe ilişkin olumlu duyuşsal iyi oluş algısını; düşük hoşnutluk ve yüksek uyarılmışlık ile düşük hoşnutluk ve düşük uyarılmışlık ise olumsuz duyuşsal iyi oluş algııını göstermektedir.

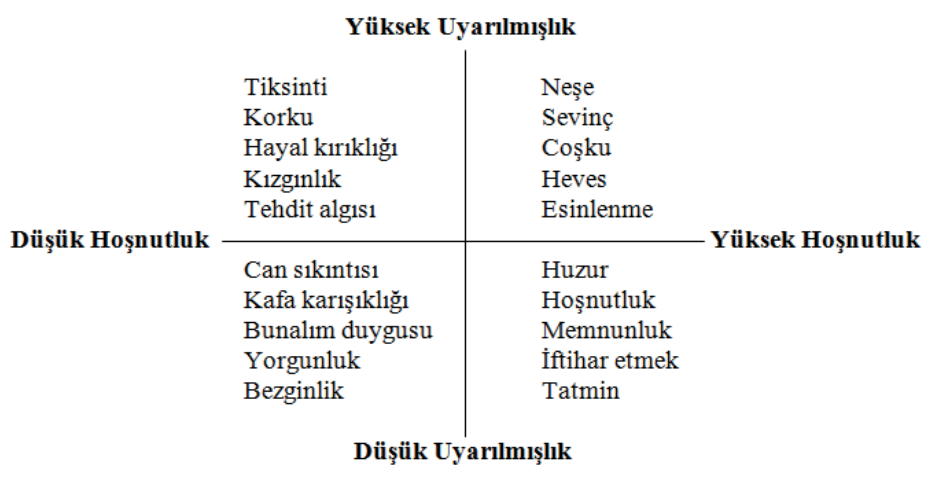

Şekil 1. Van Katwyk ve Arkadaşlarının (2000) Oluşturduğu İşe İlişsin Duyuşsal İyi Oluş Algısı Modeli

İş talepleri, çalışanın karşılayabileceğinden fazla olduğu takdirde, tükenmişlik ve işi bırakmayla sonuçlanabilmektedir (Bakker, Demerouti ve Schaufeli, 2003). İş yükünün fazlalığı uzun vadede fiziksel rahatsızlıkların yanı sıra, çalışanın duygusal açıdan yıpranmasını da beraberinde getirerek, depresyona yol açmaktadır (Hakanen, Schaufeli ve Ahola, 2008). Rol belirsizliği ve rol çatışması da iş doyumunun düşmesi ve tükenmişlik ile ilişkili görünmektedir (Sabuncuoğlu, 2008). Taştan (2014) iş yükü, rol belirsizliği, rol çatışması ve iş güvencesizliğiyle değerlendirilen iş talepleri ile çalışmaya tutkunluk arasında negatif ilişkiler olduğunu belirlemiştir. Turgut (2011) ise, iş yükünün, iş-aile çatışması aracılığıyla, çalışmaya tutkunluğun dinçlik ve adanmışlık boyutları üzerinde olumsuz etkiler ortaya koyduğunu belirtmiştir. Balducci, Schaufeli ve Fraccaroli (2011) iş talepleri ile çalışanların amaç karşıtı davranışları arasında pozitif yönlü bir ilişki oldugunu bildirmişlerdir. İş taleplerinin ve bu çerçevede değerlendirilen, rol çatışması, rol belirsizliği ve aşırı iş yükünün, çalışanların işe ilişkin duyuşsal iyi oluş algıları üzerinde olumsuz bir etkiye sahip olduğu da görülmektedir (Nordenmark, Vinberg ve Strandh, 2012; Vandenberghe, Panaccio, Bentein, Mignonac ve Roussel, 2011). Diğer yandan, bireyin duyuşsal iyi oluş algısı üzerinde iş stresinin de olumsuz etkileri bulunmaktadır (Morris ve Long, 2002). İş talepleri ile bireyin yetkinlikleri arsında uyuşmazlık olduğu takdirde, stres düzeyi ve olumsuz duygular artmaktadır (Lazarus ve Folkman, 1984). Webster, Beehr ve Love (2011), çalışanların iş yükünü, rol çatışmasını ve rol belirsizli- 
ğini engel olarak algıladıklarını, bu algıların stres düzeyini artırdığını ve bunun da çal1şanların psikolojik iyi oluşu üzerinde olumsuz bir etki yarattığını göstermişlerdir. İş stresini artıran unsurların, bireyin duyuşsal iyi oluş algısını da olumsuz yönde etkileyebildiği görülmekte, bu bağlamda, iş taleplerindeki artışın, çalışanın işe ilişkin olumsuz duyuşsal iyi oluş algısını artırabileceği düşünülmektedir.

\section{İş Yerinde Mizah Yoluyla Başa Çıkma ve Biçimlendirici Rolü}

Son yıllarda özellikle pozitif psikoloji alanında çalışan araştırmacılar tarafından ilgi gören mizah olgusu, karmaşık bir yapıya sahiptir. Mizah, bireyin psikolojik durumunu ve sosyal koşullarını destekleyici bir kavram olarak öne çıkmaktadır. İş yerinde mizah söz konusu olduğunda ise, mizahın dört farklı başa çıkma tarzı çerçevesinde kullanıldığı görülmektedir: Öncel odakl1, tepki odaklı, araçsal sosyalleştirici ve araçsal saldırgan/ manipülatif başa çıkma (Doosje, De Goede, Van Doornen ve Goldstein, 2010). Öncel odaklı başa çıkma, iş yerinde meydana gelen stres yaratıcı olayları bilişsel olarak yeniden değerlendirmeyi vurgularken, tepki odaklı başa çıkma, iş yerindeki stresli olaylar karşısında oluşan olumsuz duyguyu hafifletmek, ondan kaçınmak ya da onu azaltmak amacıyla mizahı kullanmayı vurgular. Araçsal sosyalleştirici başa çıkma, iş yerinde stresli durumlar oluştuğunda, diğer çalışanların olumsuz duygularını azaltmak üzere mizahı kullanmayı ifade ederken, araçsal saldırgan/manipülatif başa çıkma, iş yerinde stres yaratan olaylar karşısında, diğer çalışanlarda olumsuz duygular uyandırarak kendi olumsuz duygularını azaltma yolunu seçmeyi kapsar.

Mizahın iş yaşamındaki rolünü inceleyen çalışmaların sayısı gün geçtikçe artmaktadır. Mizah iş yerinde oluşan gerginliklerin azaltılmasında, stresin hafifletilmesinde önemli bir rol oynamakta (Smith, Harrington ve Neck, 2000), bu sayede, iş ortamındaki güçlüklerle başa çıkmada etkili bir yöntem olarak öne çıkmaktadır. Mizahın, iş yerindeki sosyal ilişkilerin gelişmesinde de önemli işlevleri bulunduğu görülmektedir (Holmes ve Marra, 2002). Mizah yoluyla iş ortamında oluşan pozitif duygular, grup içindeki dayanışmaya katkı sağlamakta, çalışanların moralini yükseltmektedir (Duncan, 1982). Bu bulgular, mizahın iş ortamındaki stresi azaltmak suretiyle, bireyin işe ilişkin duyuşsal iyi oluş algısını da etkileyebileceğini düşündürmektedir. Malik ve Noreen (2015), iş stresi ile duyuşsal iyi oluş arasındaki ilişkide algılanan örgütsel desteğin biçimlendirici rolü olduğunu ortaya koymuşlardır. Bu bağlamda, iş taleplerinin, çalışanın iyi oluşu üzerindeki olumsuz etkilerini azaltabilecek unsurların önem arz ettiği ve bu destekleyici unsurların mizah kullanımı gibi farklı kaynaklara yönelmek suretiyle de sağlanabileceği 
düşünülmektedir. Mizah, iş yerinde, çalışanların bilişsel, duygusal ve davranışsal tepkilerinde belirleyici rol oynamaktadır (Kohler ve Ruch, 1996). Bu bağlamda, iş yerinde karşılaşılabilecek güçlüklerle başa çıkmada, mizahın kullanımının, çalışanın iyi oluşuna olumlu katkılar sağlamakla birlikte, olumsuz duygularını hafifletici etkisinin de bulunduğu düşünülmektedir. Özellikle günümüz koşullarında, iş taleplerindeki artışla birlikte çoğalacağı düşünülen işe ilişkin olumsuz duyuşsal iyi oluş algılarının, mizah yoluyla azaltılabileceği öngörülmektedir. Bu noktadan hareketle, araştırma hipotezleri aşağıdaki şekilde oluşturulmuştur:

$H 1$ : İş taleplerinin, işe ilişkin olumsuz duyuşsal iyi oluş algısı üzerindeki etkisinde iş yerinde mizah yoluyla başa çıkma eğilimi biçimlendirici olacaktır; iş yerinde mizah yoluyla başa çıkma eğilimi arttıkça, iş taleplerinin işe ilişkin olumsuz duyuşsal iyi oluş alg1sı üzerindeki pozitif etkisi zayıflar.

H2: İş taleplerinin dört faktörünün, işe ilişkin olumsuz duyuşsal iyi oluş algısı üzerindeki etkisinde iş yerinde mizah yoluyla başa çıkma eğilimi biçimlendirici olacaktır; iş yerinde mizah yoluyla başa çıkma eğilimi arttıkça, iş taleplerinin a) iş yükü, b) duygusal talepler, c) duygusal uyumsuzluk ve d) örgütsel değişiklikler faktörlerinin işe ilişkin olumsuz duyuşsal iyi oluş algısı üzerindeki pozitif etkisi zayıflar.

Araştırmanın değişkenleri arasındaki ilişkilerin şematik modeli Şekil 2'de görülmektedir.

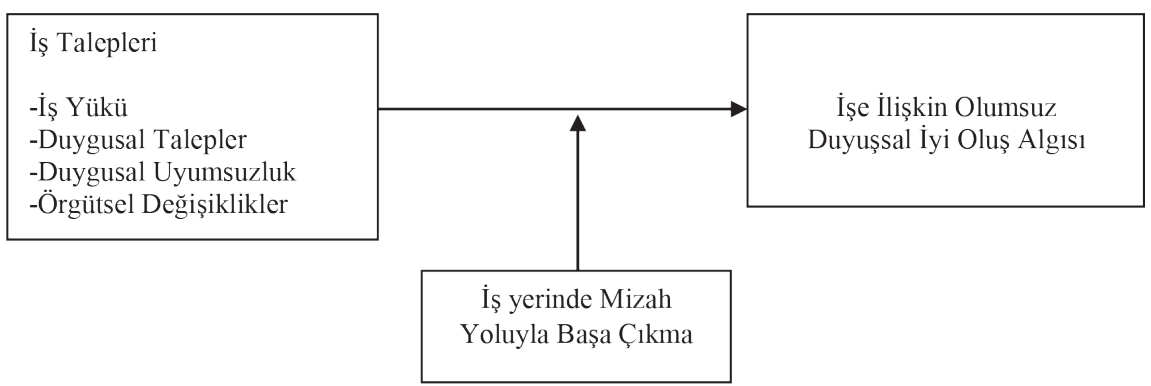

Şekil 2. İş talepleri, İşe İlişkin Olumsuz Duyuşsal İyi Oluş Algıları ve İş yerinde Mizah Yoluyla Başa Çıkma Arasındaki İlişkileri Gösteren Araştırma Modeli 


\section{YÖNTEM}

\section{Örneklem}

Bu araştırmanın örneklemini Türkiye'nin farklı şehirlerinde, duygusal, bilişsel ve fiziksel iş taleplerinin yoğun olduğu düşünülen eğitim ve sağlık sektörlerinde çalışmakta olan 319 katılımcı oluşturmaktadır. Katılımcıların tamamı üniversite mezunu olup, büyük bir çoğunluğu (\% 94) lisansüstü dereceye sahiptir. Cinsiyetleri bakımından dengeli bir dağılım söz konusu olan (\% 47 kadın ve \%53 erkek) katılımcıların yaşları 24 ile 66 arasında (Ort. $=41, \mathrm{SS}=9.50)$ ve çalışma süreleri 1 y1l ile 49 y1l arasında (Ort. $=17, S S$ = 9.68) değişmektedir. Ayrıca, katılımcıların \%31'i yöneticilik pozisyonunda çalışmaktadir.

\section{Veri Toplama Araçları}

İş Talepleri ve İş Kaynakları Ölçeği. İş taleplerini ölçmek üzere Xanthopoulou ve arkadaşları (2007) tarafından geliştirilen, iş yükü (4 madde), duygusal talepler (6 madde), duygusal uyumsuzluk (5 madde) ve örgütsel değişiklikler (7 madde) olmak üzere 4 faktör ve toplam 22 maddeden oluşan ölçek kullanılmıştır. Xanthopoulou ve arkadaşları (2007) tarafından elde edilen bulgulara göre 4 faktörün Cronbach alfa iç tutarlık katsayıları .77 ile .86 aralığındadır. Ölçeğin Metin (2010) tarafından uyarlaması yapılmış Türkçe versiyonunun 4 faktörüne ait Cronbach alfa iç tutarlık katsayıları .66 ile .75 aralığındadır. Ölçekteki maddeler 1 (Hiçbir zaman) ile 5 (Her zaman) arasında uzanan 5 basamaklı Likert tipi skala üzerinden cevaplandırılmıştır. Dört faktörden alınan puanların toplanmasıyla iş talepleri için toplam puan hesaplanmaktır; alınan yüksek puan iş taleplerinin yüksek olduğunu göstermektedir.

İşe İlişkin Duyuşsal İyi Oluş Algısı Ölçeği. İşe ilişsin olumsuz duyuşsal iyi oluş algısını ölçmek üzere Van Katwyk ve arkadaşları (2000) tarafından geliştirilen, olumlu ve olumsuz olmak üzere 2 ana boyutu bulunan İşe İlişkin Duyuşsal İyi Oluş Algısı Ölçeği’nin olumsuz ana boyutu (10 madde, Cronbach $\alpha=.92)$ kullanılmıştır. Ölçek Bayram, Aytaç, Bilgel ve Kuşdil (2004) tarafından Türkçe’ye uyarlanmış ve işe ilişkin olumsuz duyuşsal iyi oluş algısı ana boyutunun Cronbach alfa iç tutarlık katsayısı 93 olarak rapor edilmiştir. Ölçekteki maddeler 1 (Hiçbir zaman) ile 5 (Çok sık) arasında uzanan 5 basamaklı Likert tipi skala üzerinden cevaplandırılmıştır. Buna göre, ölçekten alınan yüksek puan işe ilişkin olumsuz duyuşsal iyi oluş algısının yüksek olduğunu göstermektedir. 
İş Yerinde Mizah Yoluyla Başa Çıkma Ölçeği. İş yerinde mizah yoluyla başa çıkma becerisini ölçmek üzere Doosje ve arkadaşları (2010) tarafından geliştirilen ölçek kullanılmıştır. Yirmi üç maddeden oluşan ölçeğin, öncel odaklı başa çıkma (9 madde), tepki odaklı başa çıkma (4 madde), araçsal saldırgan/manipülatif başa çıkma (7 madde) ve araçsal sosyalleştirici başa çıkma ( 3 madde) olmak üzere 4 faktörü bulunmaktadır. Doosje ve arkadaşları (2010) tarafından elde edilen bulgulara göre Cronbach alfa iç tutarlık katsayısı .73 ile .82 arasında değişmektedir. Test-tekrar test korelasyon katsayısı tüm ölçek için .71 olarak bulunmuştur. Ölçeğin Türkçe'ye uyarlanması ve güvenirlik geçerlik çalışmaları Oktuğ, Turgut ve Ünal (2018) tarafından yapılmış ve Cronbach alfa iç tutarlık katsayılarının .79 ile 91 arasında değiştiği ve ölçeğin faktör ve ölçüt geçerliğinin bulunduğu tespit edilmiştir. Ölçekteki maddeler 1 (Hiçbir zaman) ile 5 (Çok slk) arasında uzanan 5 basamaklı Likert tipi skala üzerinden cevaplandırılmıştır. Buna göre, ölçekten alınan yüksek puan iş yerinde mizah yoluyla başa çıkmanın yüksek olduğunu göstermektedir.

\section{İşlem}

Araştırmanın örneklemine, kolayda ulaşılabilir ve kartopu örneklem yöntemleri ile ulaşılmıştır. Ölçüm araçları çevrimiçi hazırlanan bir anket sitesi aracılığıyla elektronik posta yöntemi ile katılımcılara ulaştırılmıştır ve onların da çevrelerindeki çalışanlara iletmesi ile örneklem sayısı arttırılmıştır. Anketin cevaplanma süresi 15-20 dakika arasında değiş̧mektedir. Anket 730 kişiye ulaştırılmış, 2 ay içerisinde 319 kişiden yanıt gelmiştir. Anketin cevaplanma oranı \%43.7'dir. Anketin ilk sayfasında katılımcıların cevaplarının saklı kalıp sadece bilimsel araştırma için kullanılacağına ve araştırmanın amacına dair bilgi verilmiştir.

\section{BULGULAR}

\section{Ölçeklerin Güvenirlikleri ve Değişkenler Arası Korelasyonlar}

İlk olarak, ölçeklerin iç tutarlılık seviyelerini tespit etmek için Cronbach Alfa Güvenirlik Analizi uygulanmış ve her bir ölçeğin yüksek iç tutarlılık katsayısına sahip olduğu saptanmıştır (Bkz. Tablo 1). Bununla birlikte, araştırma değişkenlerine ait veriler tek bir zaman diliminde aynı katılımcılardan ve her değişken için aynı skala kullanılarak toplandığından, iç tutarlılık seviyelerinin yanılgılı olmasına sebep olabilecek ortak yöntem yanlılığının (common method bias) bulunup bulunmadığı test edilmelidir. Bunun için, en yaygın kullanılan yöntemlerden biri olan Harman'ın tek faktör skoru (de- 
ğişkenlerin ölçümünde kullanılan tüm maddelerin ortak faktöre yüklenmesi; Podsakoff, MacKenzie, Lee ve Podsakoff, 2003; Podsakoff ve Organ, 1986) uygulanmıştır. Tek faktör için toplam varyansın \%26.6 olduğu tespit edilmiş ve bu değer \%50'den küçük olduğundan ortak yöntem yanlılığının verileri ve sonuçları etkilemediği yargısına varılmıştır.

Ardından, değişkenler arasındaki korelasyon katsayıları hesaplanmıştır. Elde edilen bulgulara göre, işe ilişkin olumsuz duyuşsal iyi oluş algısının, iş yerinde mizah yoluyla başa çıkma ve iş talepleri ile arasındaki korelasyon katsayıları aynı büyüklüktedir, ancak beklendiği üzere ilişkinin yönü iş talepleri ile pozitif $(r(317)=.44, p<.001)$, iş yerinde mizah yoluyla başa çıkma ile negatiftir $(r(317)=-.44, p<.001)$. Ayrıca, iş taleplerinin her bir faktörü de olumsuz duyuşsal iyi oluş algısı ile pozitif yönde ilişkilidir. Diğer yandan, iş talepleri ve faktörleri ile iş yerinde mizah yoluyla başa çıkma arasında istatistiksel olarak anlamlı bir ilişki bulunmamaktadır (Bkz. Tablo 1).

Tablo 1. Değişkenlere Ait Tanımlayıcı İstatistikler, Güvenirlik Katsayıları ve Korelasyonlar

\begin{tabular}{lccccccccc}
\hline & Ort. & SS & $\mathbf{1}$ & $\mathbf{2}$ & $\mathbf{3}$ & $\mathbf{4}$ & $\mathbf{5}$ & $\mathbf{6}$ & $\mathbf{7}$ \\
\hline 1.İșe İliş̧kin Olumsuz Duyuşsal İyi Oluş Algısı & 2.31 & 1.00 & $(.95)$ & -.44 & .44 & .25 & .34 & .30 & .42 \\
2.İș yerinde Mizah Yoluyla Başa Çıma & 2.73 & 0.70 & & $(.95)$ & -.07 & -.10 & -.01 & -.02 & -.08 \\
3.İş Talepleri (IT) & 3.03 & 0.59 & & & $(.90)$ & .73 & .80 & .75 & .73 \\
4.İT- İş Yükü & 3.50 & 0.74 & & & & $(.81)$ & .48 & .41 & .34 \\
5.İT- Duygusal Talepler & 3.00 & 0.78 & & & & & $(.84)$ & .52 & .42 \\
6.İT- Duygusal Uyumsuzluk & 3.00 & 0.75 & & & & & & $(.87)$ & .37 \\
7.İT- Örgütsel Değişiklikler & 2.62 & 0.87 & & & & & & & $(.87)$ \\
\hline
\end{tabular}

Not: Korelasyon katsayıları anlamlılıkları: $r=|.12-.14|, p<.05 ; r=|.15-.19|, p<.01 ; r>|.20|, p<.001$.

Güvenirlik katsayıları diyagonalde parantez içinde sunulmuştur.

\section{Hipotez Testi}

Araştırmanın hipotezlerini test etmek üzere hiyerarşik regresyon ve basit eğim (simple slope) analizleri uygulanmış, etkileşim grafikleri oluşturulmuştur. Hiyerarşik regresyon uygulanmadan önce yordayıcı ve biçimlendirici değişkenler standardize edilmiş ve çarpımları alınmıştır. Regresyon analizinde birinci modele yordayıcı değişken, ikinci modele biçimlendirici değişken ve üçüncü modele yordayıcı ve biçimlendirici değişkenlerin etkileşim halleri alınmıştır.

Tablo 2'de görüldüğü gibi, birinci modelde iş taleplerinin işe ilişkin olumsuz duyuşsal iyi oluş algısı üzerinde istatistiksel olarak anlamlı ve pozitif yönlü etkisi $(B=0.45$, $\left.S H=0.06, R^{2}=.19\right)$ bulunmaktadır. İkinci modele iş yerinde mizah yoluyla başa çıkma eklendiğinde, modelin açıklayıcılık gücünün istatistiksel olarak anlamlı düzeyde arttığı 
$\left(\Delta R^{2}=.18\right)$, ayrıca bu değişkenin işe ilişkin olumsuz duyuşsal iyi oluş algısı üzerinde beklendiği gibi negatif yönlü etkisi $(B=-0.44, S H=0.05)$ olduğu saptanmıştır. Üçüncü modelde, işe ilişkin olumsuz duyuşsal iyi oluş algısı üzerinde, iş taleplerinin bağımsız etkisinin biraz azaldığ $1(B=0.37, S H=0.05)$, iş yerinde mizah yoluyla başa çıkmanın etkisinin değişmediği $(B=-0.44, S H=0.05)$ ayrıca bu iki değişkenin etkileşim halinin işe ilişkin olumsuz duyuşsal iyi oluş algısı üzerinde istatistiksel olarak anlamlı bir etkisi ( $\left.B=-0.15, S H=0.05, \Delta R^{2}=.02\right)$ olduğu saptanmıştır.

Tablo 2. İş Talepleri ile İş yerinde Mizah Yoluyla Başa Çıkma Etkileşiminin İşe İlişkin Olumsuz Duyuşsal İyi Oluş Algııı Üzerindeki Etkisi

\begin{tabular}{llccccc}
\hline Model & Değişkenler & $\boldsymbol{B}$ & $\boldsymbol{S H}(\boldsymbol{B})$ & $\boldsymbol{\beta}$ & $\mathbf{R}^{2}$ & $\boldsymbol{\Delta R}^{2}$ \\
\hline 1 & İş̧ talepleri & 0.45 & 0.06 & $.44^{*}$ & $.19^{*}$ & $.19^{*}$ \\
2 & İş talepleri & 0.42 & 0.05 & $.41^{*}$ & $.37^{*}$ & $.18^{*}$ \\
& Mizah & -0.44 & 0.05 & $-.42^{*}$ & & \\
3 & İş talepleri & 0.37 & 0.05 & $.37^{*}$ & $.39^{*}$ & $.02 *$ \\
& Mizah & -0.44 & 0.05 & $-.43^{*}$ & & \\
& İș talepleri* Mizah & -0.15 & 0.05 & $-.16^{*}$ & & \\
\hline
\end{tabular}

${ }^{*} p<.001$.

Uygulanan basit eğim (simple slope) analizi (Aiken ve West, 1991), iş yerinde mizah yoluyla başa çıkma eğiliminin hem yüksek hem de düşük olduğu durumda, iş taleplerinin işe ilişkin olumsuz duyuşsal iyi oluş algıısı üzerindeki pozitif etkisinin istatistiksel olarak anlamlı olduğunu göstermiştir (yüksek mizah için: $b=.24, t=3.82, p<$ .001 ; düşük mizah için: $b=.41, t=9.17, p<.001)$. Her iki basit eğimin de istatistiksel olarak anlamlı olması üzerine; iş taleplerinin işe ilişkin olumsuz duyuşsal iyi oluş algıs1 üzerindeki etkisinin mizah yoluyla başa çıkma eğiliminin düşük ve yüksek olduğu durumlarda farklı olup olmadığını test etmek için basit eğimlerde fark testi (Soper, 2019) uygulanmıştır. Bu analiz, mizah yoluyla başa çıkma eğiliminin düşük ve yüksek olduğu durumlarda basit eğimler arasındaki farkın istatistiksel olarak anlamlı olduğunu $(t(604)=2.10, p<.05)$ göstermiştir. Bu sonuçlara göre, iş taleplerinin olumsuz duyuşsal iyi oluş algısı üzerindeki pozitif etkisi, iş yerinde mizah yoluyla başa çıkma eğilimi yüksek olduğu durumda, düşük olduğu duruma kıyasla daha zayıftır. Değişkenlere ilişkin eğimler Şekil 3 'te sunulmaktadır. 


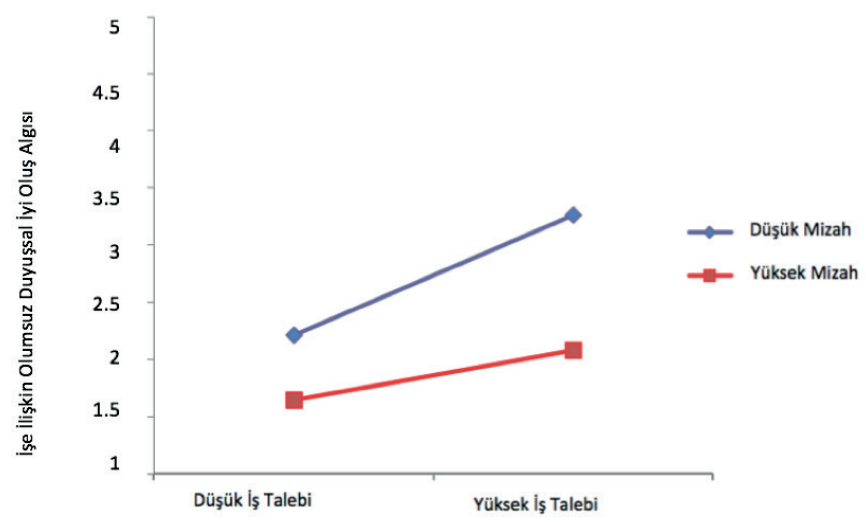

Şekil 3. İş Talepleri ile İş Yerinde Mizah Yoluyla Başa Çıkma Etkileşiminin İşe İlişsin Olumsuz Duyuşsal İyi Oluş Algısı Üzerindeki Etkisi

Böylece, "İş taleplerinin, işe ilişkin olumsuz duyuşsal iyi oluş algısı üzerindeki etkisinde iş yerinde mizah yoluyla başa çıkma eğilimi biçimlendirici olacaktır; iş yerinde mizah yoluyla başa çıkma eğilimi arttıkça, iş taleplerinin işe ilişkin olumsuz duyuşsal iyi oluş algısı üzerindeki pozitif etkisi zayıflar” şeklinde kurulan hipotez (H1) desteklenmiştir.

İş taleplerinin her bir 4 faktörü ile işe ilişkin olumsuz duyuşsal iyi oluş algısı arasındaki ilişkilerde, iş yerinde mizah yoluyla başa çıkmanın biçimlendirici rolü üstlenip üstlenmediğini görmek için de yine hiyerarşik regresyon ve basit eğim analizleri uygulanmış, etkileşim grafikleri oluşturulmuştur.-

Tablo 3'de yer alan sonuçlar, iş yerinde mizah yoluyla başa çıkmanın, iş yükü $\left(\Delta R^{2}=\right.$ .02 , Bkz. Model 3), duygusal talepler $\left(\Delta R^{2}=.03\right.$, Bkz. Model 3), duygusal uyumsuzluk $\left(\Delta R^{2}=.01\right.$, Bkz. Model 3$)$ ve örgütsel değişiklikler $\left(\Delta R^{2}=.01\right.$, Bkz. Model 3) ile etkileşimlerinin işe ilişkin olumsuz duyuşsal iyi oluş algısı üzerinde istatistiksel olarak anlamlı etkisi olduğunu göstermektedir.

Basit eğim analizi sonuçlarına göre, iş yükünün işe ilişkin olumsuz duyuşsal iyi oluş algısı üzerindeki pozitif etkisi, iş yerinde mizah yoluyla başa çıkma eğilimi düşük olduğu durumda istatistiksel olarak anlamlı $(b=.34, t=5.16, p<.001)$; iş yerinde mizah yoluyla başa çıkma eğilimi yüksek olduğu durumda $(b=.08, t=1.26, p>.05)$ istatistiksel olarak anlamsızdır. Şekil 4’ten de izlendiği gibi, iş yükü ile işe ilişkin 
Tablo 3. İş Taleplerinin Faktörleri ile İş yerinde Mizah Yoluyla Başa Çıkma Etkileşiminin İşe İlişkin Olumsuz Duyuşsal İyi Oluş Algısı Üzerindeki Etkisi

\begin{tabular}{|c|c|c|c|c|c|c|}
\hline Model & Değişkenler & $\boldsymbol{B}$ & $S H(B)$ & $\beta$ & $\mathbf{R}^{2}$ & $\Delta \mathbf{R}^{2}$ \\
\hline 1 & İş yükü & 0.26 & 0.06 & $.25 * * *$ & $.06^{* * *}$ & $.06 * * *$ \\
\hline \multirow[t]{2}{*}{2} & İş yükü & 0.21 & 0.05 & $.21 * * *$ & $.24 * * *$ & $.18^{* * *}$ \\
\hline & Mizah & -0.44 & 0.05 & $-.42 * * *$ & & \\
\hline \multirow[t]{3}{*}{3} & İş yükü & 0.21 & 0.05 & $.21 * * *$ & $.26^{* * *}$ & $.02 * *$ \\
\hline & Mizah & -0.45 & 0.05 & $-.43 * * *$ & & \\
\hline & İş yükü* Mizah & -0.13 & 0.04 & $-.14 * *$ & & \\
\hline 1 & Duygusal talep & 0.35 & 0.05 & $.34 * * *$ & $.12 * * *$ & $.12 * * *$ \\
\hline \multirow[t]{2}{*}{2} & Duygusal talep & 0.35 & 0.05 & $.34 * * *$ & $.31 * * *$ & $.19 * * *$ \\
\hline & Mizah & -0.46 & 0.05 & $-.44 * * *$ & & \\
\hline \multirow[t]{3}{*}{3} & Duygusal talep & 0.33 & 0.05 & $.33 * * *$ & $.34 * * *$ & $.03 * * *$ \\
\hline & Mizah & -0.46 & 0.05 & $-.45 * * *$ & & \\
\hline & Duygusal talep*Mizah & -0.16 & 0.05 & $-.16^{* * *}$ & & \\
\hline 1 & Duygusal uyumsuzluk & 0.30 & 0.05 & $.30 * * *$ & $.09 * * *$ & $.09 * * *$ \\
\hline \multirow[t]{2}{*}{2} & Duygusal uyumsuzluk & 0.29 & 0.05 & $.29 * * *$ & $.28 * * *$ & $.19 * * *$ \\
\hline & Mizah & -0.45 & 0.05 & $-.44 * * *$ & & \\
\hline \multirow[t]{3}{*}{3} & Duygusal uyumsuzluk & 0.27 & 0.05 & $.27 * * *$ & $.29 * * *$ & $.01^{*}$ \\
\hline & Mizah & -0.46 & 0.05 & $-.44 * * *$ & & \\
\hline & Duygusal uyumsuzluk* Mizah & -0.10 & 0.04 & $-.10 *$ & & \\
\hline 1 & Örgütsel değişiklik & 0.41 & 0.05 & $.42 * * *$ & $.18^{* * *}$ & $.18 * * *$ \\
\hline \multirow[t]{2}{*}{2} & Örgütsel değişiklik & 0.38 & 0.04 & $.39 * * *$ & $.35 * * *$ & $.17 * * *$ \\
\hline & Mizah & -0.43 & 0.05 & $-.41 * * *$ & & \\
\hline \multirow[t]{3}{*}{3} & Örgütsel değiş̧iklik & 0.37 & 0.04 & $.38 * * *$ & $.36 * * *$ & $.01^{*}$ \\
\hline & Mizah & -0.43 & 0.05 & $-.42 * * *$ & & \\
\hline & Örgütsel değişiklik* Mizah & -0.11 & 0.04 & $-.11 *$ & & \\
\hline
\end{tabular}

${ }^{*} p<.05 ; * * p<.01 ; * * *<.001$.

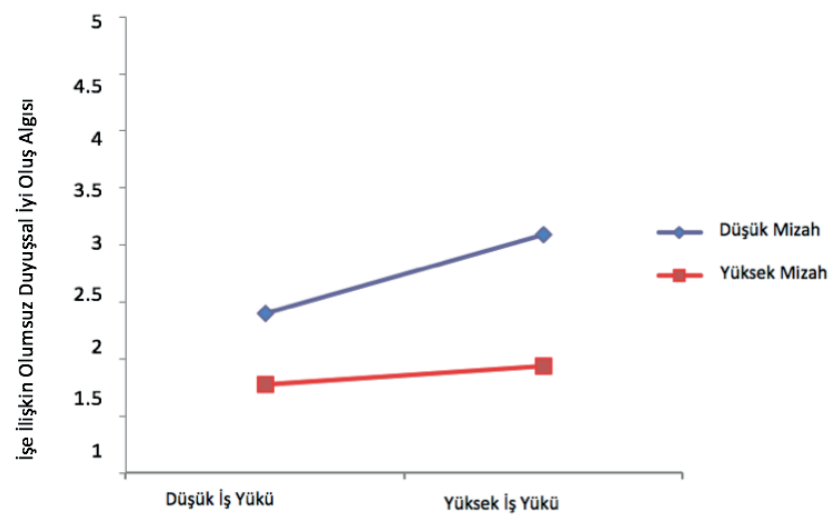

Şekil 4. İş Yükü ile İş Yerinde Mizah Yoluyla Başa Çıkma Etkileşiminin İşe İlişkin Olumsuz Duyuşsal İyi Oluş Algısı Üzerindeki Etkisi 
olumsuz duyuşsal iyi oluş algıısı arasındaki pozitif ilişki, çalışanların iş yerinde mizah yoluyla başa çıkma eğilimleri yüksek olduğu durumda, düşük olduğu duruma kıyasla, daha zayıftır.

Basit eğim analizi, duygusal taleplerin işe ilişkin olumsuz duyuşsal iyi oluş algısı üzerindeki pozitif etkisinin, iş yerinde mizah yoluyla başa çıkma eğilimi yüksek olduğu durumda $(b=.17, t=2.64, p<.01)$ ve düşük olduğu durumda $(b=.49, t=7.89, p$ $<.001$ ) istatistiksel olarak anlamlı olduğunu göstermiştir. Her iki basit eğimin de istatistiksel olarak anlamlı olması üzerine; basit eğimlerde fark testi uygulanmış ve mizah yoluyla başa çıkma eğiliminin düşük ve yüksek olduğu durumlarda basit eğimler arasındaki farkın istatistiksel olarak anlamlı olduğu $(t(634)=3.51, p<.001)$ tespit edilmiştir. Buna göre, duygusal taleplerin olumsuz duyuşsal iyi oluş algısı üzerindeki pozitif etkisi, iş yerinde mizah yoluyla başa çıkma eğilimi yüksek olduğu durumda, düşük olduğu duruma kıyasla, daha zayıftır. Değişkenlere ilişkin eğimler Şekil 5'te sunulmaktadir.

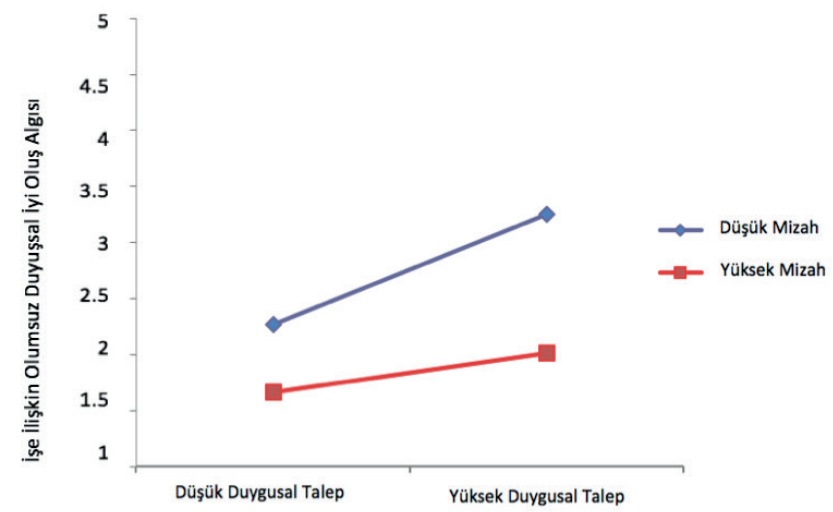

Şekil 5. Duygusal Talep ile İş Yerinde Mizah Yoluyla Başa Çıkma Etkileşiminin İşe İlişkin Olumsuz Duyuşsal İyi Oluş Algısı Üzerindeki Etkisi

Basit eğim analizi, duygusal uyumsuzluğun işe ilişkin olumsuz duyuşsal iyi oluş algısı üzerindeki pozitif etkisinin, iş yerinde mizah yoluyla başa çıkma eğilimi yüksek olduğu durumda $(b=.18, t=2.61, p<.01)$ ve düşük olduğu durumda $(b=.37, t=$ $6.17, p<.001$ ) istatistiksel olarak anlamlı olduğunu göstermiştir. Her iki basit eğimin de istatistiksel olarak anlamlı olması üzerine; basit eğimlerde fark testi uygulanmış ve 
mizah yoluyla başa çıkma eğiliminin düşük ve yüksek olduğu durumlarda basit eğimler arasındaki farkın istatistiksel olarak anlamlı olduğu $(t(634)=2.06, p<.05)$ tespit edilmiştir. Buna göre, duygusal uyumsuzluğun olumsuz duyuşsal iyi oluş algısı üzerindeki pozitif etkisi, iş yerinde mizah yoluyla başa çıkma eğilimi yüksek olduğu durumda, düşük olduğu duruma kıyasla, daha zayıftır. Değişkenlere ilişkin eğimler Şekil 6' da sunulmaktadir.

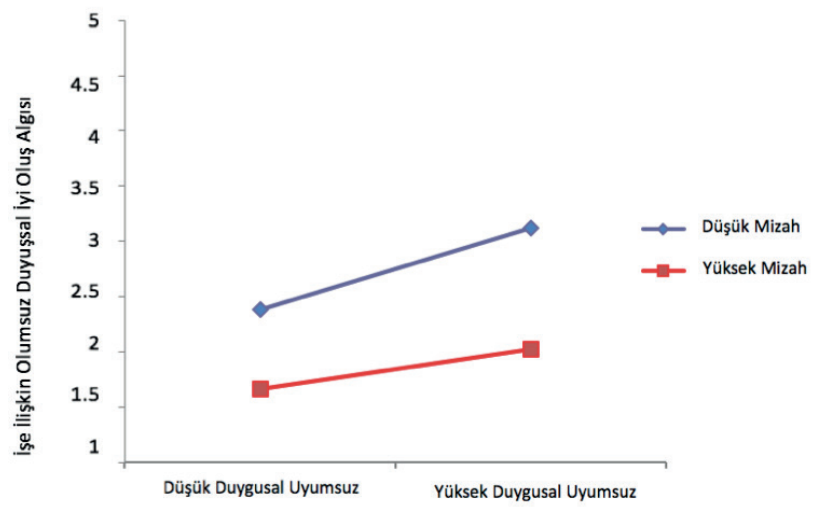

Şekil 6. Duygusal Uyumsuzluk ile İş Yerinde Mizah Yoluyla Başa Çıkma Etkileşiminin İşe İlişkin Olumsuz Duyuşsal İyi Oluş Algısı Üzerindeki Etkisi

Basit eğim analizi, örgütsel değişikliklerin işe ilişkin olumsuz duyuşsal iyi oluş algısı üzerindeki pozitif etkisinin, iş yerinde mizah yoluyla başa çıkma eğilimi yüksek olduğu durumda $(b=.26, t=4.07, p<.001)$ ve düşük olduğu durumda $(b=.47, t=$ 7.93, $p<.001)$ istatistiksel olarak anlamlı olduğunu göstermiştir. Her iki basit eğimin de istatistiksel olarak anlamlı olması üzerine; basit eğimlerde fark testi uygulanmış ve mizah yoluyla başa çıkma eğiliminin düşük ve yüksek olduğu durumlarda basit eğimler arasındaki farkın istatistiksel olarak anlamlı olduğu $(t(634)=2.37, p<.01)$ tespit edilmiştir. Buna göre, örgütsel değişikliklerin olumsuz duyuşsal iyi oluş algısı üzerindeki pozitif etkisi, iş yerinde mizah yoluyla başa çıkma eğilimi yüksek olduğu durumda, düşük olduğu duruma kıyasla, daha zayıftır. Değişkenlere ilişkin eğimler Şekil 7'de sunulmaktadir. 


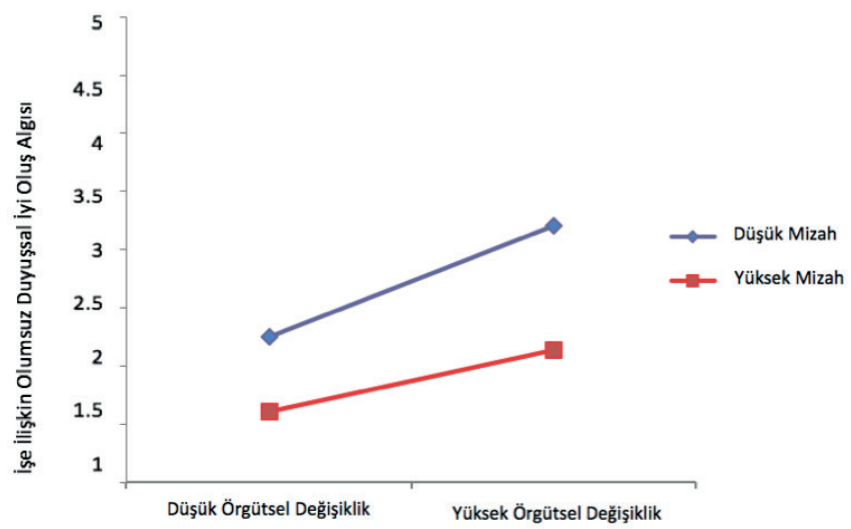

Şekil 7. Örgütsel Değişiklikler ile İş Yerinde Mizah Yoluyla Başa Çıkma Etkileşiminin İşe İlişkin Olumsuz Duyuşsal İyi Oluş Algısı Üzerindeki Etkisi

Özetle, elde edilen sonuçlar, iş yerinde mizah yoluyla başa çıkma eğilimi güçlendikçe iş taleplerinin her faktörü ile işe ilişkin olumsuz duyuşsal iyi oluş algısı arasındaki pozitif ilişkinin zayıfladığını göstermektedir. Böylece iş taleplerinin her bir faktörü için kurulan hipotezler $(H 2 a, H 2 b, H 2 c, H 2 d)$ desteklenmiştir.

\section{TARTIŞMA}

$\mathrm{Bu}$ çalışmada, iş taleplerinin çalışanda oluşturabileceği olumsuz duyuşsal iyi oluş algılarını azaltacak faktörlerin belirlenmesine katkı sağlamak üzere, çalışanların iş yerinde mizah yoluyla başa çıkma eğilimleri incelenmiş, iş talepleri ile olumsuz duyuşsal iyi oluş algısı arasındaki ilişkide, mizahın biçimlendirici rolünün bulunduğu tespit edilmiştir. Araştırma kapsamında ortaya çıkan bulgular, iş talepleri karşısındaki olumsuz duyuşsal iyi oluş algıları açısından, mizah yoluyla başa çıkma eğilimi zayıf olan kişilerin, mizah yoluyla başa çıkma eğilimi güçlü olan kişilere nazaran daha dezavantajlı durumda olabileceğine işaret etmektedir. İş talebi yüksek ve mizah yoluyla başa çıkma eğilimi düşük olan kişilerin, hem iş talebi hem de mizah yoluyla başa çıkma eğilimi yüksek olan kişilere nazaran, işe ilişkin olumsuz duyuşsal iyi oluş algılarının daha fazla olduğu gözlenmiştir. Bu bulgu, iş yerinde mizah yoluyla başa çıkma becerilerinin, yalnızca çalışanın sağlığına olumlu katkı sağlama açısından değil, aynı zamanda, iş taleplerinin karşılanması açısından da önem arz ettiğinin altını çizmektedir. 
Çalışmada iş taleplerinin faktörleri olan duygusal talepler, duygusal uyumsuzluk, iş yükü ve örgütsel değişiklikler de ayrıca ele alınmış, mizah yoluyla başa çıkma eğilimi güçlendikçe her bir faktör ile işe ilişkin olumsuz duyuşsal iyi oluş algısı arasındaki pozitif ilişkinin zayıfladığı belirlenmiştir. Duygusal taleplerin ve duygusal uyumsuzluğun duygusal tükenmişlik ile pozitif yönlü güçlü ilişkilerinin olduğu görülmektedir (Diestel ve Schmidt, 2010; Scanlan ve Still, 2019). Loh, Idris, Dollard ve Isahak (2018) yaptıkları çalışmada, örgütlerdeki psikososyal güvenlik ikliminin duygusal talepler ve duygusal tükenmiş̧lik arasındaki ilişkiyi zayıflattığını ortaya koymuşlardır. Psiko-sosyal güvenlik ikliminin odak noktası, örgüt içinde çalışanın ruh sağlığının korunmasına yönelik uygulamalar geliştirmektir (Dollard ve Bakker, 2010). İş yerinde mizah yoluyla başa çıkma eğiliminin örgüt iklimini olumlu yönde geliştireceği ve çalışanın ruh sağlığını koruyucu bir unsur olarak kabul edilebileceği düşünülmektedir. Bu bağlamda çalışmanın sonuçları, duygusal talepler ve duygusal uyumsuzluğun çalışan üzerindeki olumsuz etkilerinin hafifletilmesinde, iş yerinde mizah yoluyla başa çıkmanın örgüt iklimine katk1 sağlayan bir unsur olarak değerlendirilebileceğine işaret etmektedir. Diğer yandan, iş yükündeki artış çalışanın stres düzeyini artırmaktadır (Greenglass, Burke ve Fiksenbaum, 2001). Mizah yoluyla başa çıkma becerilerinin iş yükünden kaynaklanan stres düzeyini azalttığı ve bu bağlamda duyuşsal iyi oluş algılarını olumlu yönde şekillendirdiği düşünülmektedir. Günümüzün iş koşulları sürekli değişime ayak uydurma zorunluluğunu beraberinde getirmekte, çalışanlar açısından değişimin varlığ olabilmektedir. Değişimin kabullenilmemesi, değişime atfedilen negatif değer ve bireyin harekete geçme isteğinin düşük olması ile ortaya çıkmaktadır (Oreg ve ark., 2018). Mizah yoluyla başa çıkma eğiliminin yarattığı pozitif duygulanımın, bireyin harekete geçmedeki isteksizliğini azaltmak suretiyle değişim karşısındaki tutumunu olumlu yönde etkilediği düşünülmektedir.

Bireyin mizaha bakışı, duygusal durumu üzerinde etkilidir. Nunes, Jose ve Capelas (2018), sağlık sektöründe yaptıkları çalışmada, mizah kullanımı hakkında olumsuz görüşü olan çalışanların, olumlu görüşü olanlara nazaran daha kederli olduklarını, başkaları tarafından yanlış anlaşıldıklarına dair hislerinin daha fazla olduğunu göstermişlerdir. İş taleplerinin çalışan üzerindeki etkileri kapsamında düşünüldüğünde, bireyin mizah duygusunun güçlü olmasının talepleri karşılama sürecinde destekleyici olacağı, zayıf olmasının ise süreçte olumsuz duygularla daha fazla karşılaşacağı şeklinde yorumlanabilir. Bu bağlamda, özellikle iş taleplerinin yoğun olduğu sektörlerde, çalışanların mi- 
zah duygularını geliştirebilecekleri örgüt iklimlerinin mevcudiyeti önem kazanmaktadır. Türkiye güç mesafesi yüksek bir toplumdur (Kabasakal ve Dastmalchian, 2001), başka bir deyişle, örgütte statü farkları önem arz eder. Geniş güç mesafesinin varlığının iş yerinde mizah kullanımını kısıtlayıcı bir etken olabileceği, bu noktada cesaretlendirici örgüt iklimine daha fazla ihtiyaç duyulabileceği düşünülmektedir.

Pozitif psikoloji hareketinin örgütlere yansıması olarak kabul edilen pozitif örgütsel davranış akımı kapsamında Luthans ve Youssef (2004), çalışanların öz-yeterliliğini, iyimser tutumunu, başarı için umudunu ve psikolojik dayanıklılığını içeren pozitif psikolojik sermaye kavramını alan yazına kazandırmış, bu kavramın örgütsel sonuçlar açısından önemini vurgulamıştır. Araştırmacılar ayrıca, psikolojik sermayenin performans üzerindeki olumlu etkisinin örgütsel sonuçlara önemli yansımaları olduğunu belirtmişlerdir. İş yerinde mizah kullanımının iyimserlik ve psikolojik dayanıklılık çerçevesinde psikolojik sermayeye katkı sağladığı ve bu bağlamda, gelecekteki çalışmalarda bu hususun incelenmesinin yarar getireceği düşünülmektedir.

$\mathrm{Bu}$ çalışma kapsamında, iş taleplerinin çalışanlarda oluşturabileceği olumsuz duyuşsal iyi oluş algıları incelenmiştir. İnsanlar olumsuz uyaranlara karşı olumlu uyaranlara nazaran daha açıktırlar (Garcia, Rosenberg, Erlandsson ve Siddiqui, 2010). İş yaşamı açısından değerlendirildiğinde, olumsuz duygulardaki artışın üretkenlik karşıtı davranışları artırma (Fox, Spector ve Miles, 2001) olasılığı da dikkate alınarak, olumsuz duyuşsal iyi oluş algısını azaltacak unsurların vurgulanması önemli görülmüşstür. Artan rekabet, güçleşen koşullar, bireyleri gün geçtikçe zorlaşan, karmaşıklaşan bir çalışma ortamı ile karşı karşıya bırakmaktadır. Bu bağlamda, çalışanın olumsuz duygularında azalma sağlayabilecek her unsurun dikkatle incelenmesi yararlıdır. Yöneticilerin de bu hususlarda destekçi olmaları, gelişime açık tutumlar sergilemeleri elde edilecek yararı artıracaktır.

Çalışanın memnuniyet ekseninde ortaya çıkan ve işiyle bağlantılı genel mutluluk düzeyini yansıtan olumlu ve olumsuz duyuşsal iyi oluş algıları ayrı ayrı değerlendirilebilmektedir (Bayram ve ark., 2004). Duyuşsal iyi oluş algıları, hoşnutluk ve uyarılmışlık olmak üzere iki temel sistemden doğmakta, bu sistemler birbirinden bağımsız iki ayrı düzlemde değerlendirilmektedir (Russell, 1980). Hoşnutluğun yüksek olduğu durumlarda olumlu duyuşsal iyi oluş algısı, düşük olduğu durumlarda ise olumsuz duyuşsal iyi oluş algısı söz konusu olmakta, her iki durumda da uyarılmışlık düzeyi yüksek ya da 
düşük olabilmektedir. Başka bir deyişle, çalışanın hoşnutluk düzeyi yüksek iken, uyarılmışlık düzeyi yüksek ya da düşük olabilmekte, benzer şekilde, hoşnutluk düzeyi düşük iken, uyarılmışlık düzeyi yine yüksek ya da düşük olabilmektedir. Bu şekilde ortaya çıkan dört durum, olumlu duyuşsal iyi oluş algısı tanımı altında yüksek hoşnutluk-yüksek uyarılmışlık, yüksek hoşnutluk-düşük uyarılmışlık olarak, olumsuz duyuşsal iyi oluş alg1s1 tanımı altında ise, düşük hoşnutluk-yüksek uyarılmışıı, düşük hoşnutluk-düşük uyarılmışlık olarak yer almaktadır. Bu çalışma kapsamında, iş yerinde mizahın olumsuz duyuşsal iyi oluş algısı üzerindeki rolü ele alınmıştır. Ancak iş yerinde mizah yoluyla başa çıkma eğiliminin, çalışanların olumsuz duyuşsal iyi oluş algılarını hafifletici etkisinin bulunması, aynı zamanda olumlu duyuşsal iyi oluş algılarını artırdığı anlamına gelmemektedir. Gelecekteki çalışmalarda, iş taleplerinin olumlu duyuşsal iyi oluş algıları ile ilişkilerinin ve bu ilişki bağlamında mizahın etkilerinin incelenmesinin yararlı olacağ1 düşünülmektedir.

Finansal Destek: Yazarlar bu çalışma için finansal destek almamışlardır.

\section{Kaynakça}

Aiken, L. S. ve West, S. G. (1991). Multiple regression: Testing and interpreting interactions. Newbury Park, CA: Sage.

Bakker, A. B. ve Demerouti, E. (2008). Towards a model of work engagement. Career Development International, 13(3), 209-223. doi:10.1108/13620430810870476

Bakker, A. B., Demerouti, E., ve Schaufeli, W. B. (2003). Dual processes at work in a callcentre: An application of the job demands-resources model. European Journal of Work and Organizational Psychology, 12, 393-417. doi:10.1080/13594320344000165

Balducci, C., Schaufeli, W. B. ve Fraccaroli, F. (2011). The job demands-resources model and counterproductive work behaviour: The role of job-related affect. European Journal of Work and Organizational Psychology, 20(4), 467-496. doi:10.1080/13594321003669061

Bayram, N., Aytaç, S. Bilgel, N. ve Kuşdil, M. E. (2004). İşe ilişkin duyuşsal iyilik algısı ölçeğinin (job-related affective well-being-jaws) Türkçe versiyonunun güvenirlik çalışması. Öneri: Marmara Üniversitesi Sosyal Bilimler Enstitüsü Dergisi, 6(22), 1-7.

Crawford, S. A. ve Caltabiano, N. J. (2011). Promoting emotional well-being through the use of humour. The Journal of Positive Psychology, 6(3), 237-252. doi:10.1080/17439760.2011.577087

Demerouti, E. ve Bakker, A. B. (2011). The job demands-resources model: Challenges for future research, SA Journal of Industrial Psychology, 37(2), 1-9. doi:10.4102/sajip.v37i2.974

Demerouti, E., Bakker, A. B., Nachreiner, F. ve Schaufeli, W. B. (2001). The job demands: Resources model of burnout. Journal of Applied Psychology, 86, 499-512. doi:10.1037/0021-9010.86.3.499

Diefendorff, J. M., Greguras, G. J. ve Fleenor, J. (2016). Perceived emotional demands-abilities fit. Applied Psychology: An International Review, 65(1), 2-37. doi:10.1111/apps.12034

Diener, E. (1984). Subjective well-being. Psychological Bulletin, 95, 542-575. doi:10.1037/00332909.95.3.542 
Diener, E. (1994). Assessing subjective well-being: Progress and opportunities. Social Indicators Research, 31, 103-157. doi:10.1007/BF01207052

Diestel, S. ve Schmidt, K. H. (2010). Interactive effects of emotional dissonance and self-control demands on burnout, anxiety, and absenteeism. Journal of Vocational Behavior, 77(3), 412-424. doi:10.1016/j.jvb.2010.05.006

Dollard, M. F., ve Bakker, A. B. (2010). Psychosocial safety climate as a precursor to conducive work environments, psychological health problems, and employee engagement. Journal of Occupational and Organizational Psychology, 83, 579-599. doi:10.1348/096317909X470690

Doosje, S., De Goede, M. P. M., Van Doornen, L. P. J. ve Goldstein, J. H. (2010). Measurement of occupational humorous coping. Humor: International Journal of Humor Research, 23(3), 273-305.

Duncan, W. J. (1982), Humor in management: Prospects for administrative practice and research. Academy of Management Review, 7, 136- 142.

Emmons, R. A. ve Diener, E. (1985). Personality correlates of subjective well-being. Personality and Social Psychology Bulletin, 11, 89-97. doi:10.1177/0146167285111008

Falkenberg, I., Buchkremer, G., Bartels, M. ve Wild, B. (2011). Implementation of a manual-based training of humor abilities in patients with depression: A pilot study. Psychiatry Research, 186(2-3), 454-457. doi:10.1016/j.psychres.2010.10.009

Fox, S., Spector, P. E. ve Miles, D. (2001). Counterproductive work behavior (CWB) in response to job stressors and organizational justice: Some mediator and mediator tests for autonomy and emotions. Journal of Vocational Behavior, 59, 291-309. doi:10.1006/jvbe.2001.1803

Garcia, D., Rosenberg, P., Erlandsson, A. ve Siddiqui, A. (2010). On lions and adolescents: Affective temperaments and the influence of negative stimuli on memory. Journal of Happiness Studies 11(4), 477-495. doi:10.1007/s10902-009-9153-6

Genina, E., Haines IIIa, V.Y., Pelletierb, D., Rousseaua, V. ve Marchanda, A. (2016). Why the long hours? Job demands and social exchange dynamics. Work, 55, 539-548. doi:10.3233/WOR-162430

Greenglass, E. R., Burke, R. J. ve Fiksenbaum, L. (2001). Workload and burnout in nurses. Journal of Community \& Applied Social Psychology, 11(3), 211-215. doi:10.1002/casp.614

Hakanen, J. J., Schaufeli, W. B. ve Ahola, K. (2008). The job demands-resources model: A three-year cross-lagged study of burnout, depression, commitment, and work engagement. Work \& Stress, 22(3), 224-241. doi:10.1080/02678370802379432

Hochschild, A. R. (1983). The managed heart: Commercialization of human feeling. Berkeley, CA: University of California Press.

Holmes, J. ve Marra, M. (2002). Having a laugh at work: How humor contributes to workplace culture. Journal of Pragmatics, 34, 1683 -1710. doi:10.1016/S0378-2166(02)00032-2

Kabasakal, H. ve Dastmalchian, A. (2001). Introduction to the special issue on leadership and culture in the Middle East. Applied Psycology: An International Review, 50(4), 479-488. doi:10.1111/1464-0597.00069

Kohler, G. ve Ruch, W. (1996). Sources of variance in current sense of humor inventories: How much substance, how much method variance? Humor: International Journal of Humor Research, 9(3-4), 363- 397. doi:10.1515/humr.1996.9.3-4.363

Larsen, R. (2009). The contributions of positive and negative affect to emotional well-being. Psychological Topics, 18(2), 247-266.

Lazarus, R. S. ve Folkman, S. (1984). Stress, appraisal, and coping. New York: Springer.

Loh, M. Y., Idris, M. A., Dollard, M. F. ve Isahak, M. (2018). Psychosocial safety climate as a moderator of the moderators: Contextualizing JDR models and emotional demands effects. Journal of Occupational and Organizational Psychology, 91, 620-644. doi:10.1111/joop.12211 
Luthans, F. ve Youssef, C. M. (2004). Human, social, and now positive psychological capital management, Organizational Dynamics, 33, 143-160. doi:10.1016/j.orgdyn.2004.01.003

Malik, S. ve Noreen, S. (2015). Perceived organizational support as a moderator of affective well-being and occupational stress among teachers. Pakistan Journal of Commerce and Social Sciences, 9(3), 865-874.

Metin, B. (2010). The antecendents and consequences of burnout, work engagement and workaholism (Yayınlanmamış yüksek lisans tezi). Orta Doğu Teknik Üniversitesi, Ankara.

Morris, J. E. ve Long, B. C. (2002). Female clerical workers' occupational stress: The role of person and social resources, negative affectivity and stress appraisals, Journal of Counselling Psychology, 49(4), 395-410. doi:10.1037/0022-0167.49.4.395

Nordenmark, M., Vinberg, S. ve Strandh M. (2012). Job control and demands, work-life balance and wellbeing among selfemployed men and women in Europe. Vulnerable Groups \& Inclusion, 3(1), 1-18. doi:10.3402/vgi.v3i0.18896

Nunes, I. R., Jose, H. ve Capelas, M. L. (2018). Grieving with humor: A correlational study on sense of humor and professional grief in palliative care nurses. Holistic Nursing Practice, 32(2), 98-106. doi:10.1097/HNP.0000000000000255

Oktuğ, Z., Turgut, T. ve Ünal, Z. M. (2018). İş yerinde Mizah Yoluyla Başa Çıkma Ölçeği: Türkçe’ye uyarlanmas1, güvenilirlik ve geçerlilik çalışması. Mehmet Akif Ersoy Üniversitesi Sosyal Bilimler Enstitüsü Dergisi, 10(26), 782-797. doi:10.20875/makusobed.428079

Oreg, S., Bartunek, J. M., Lee G. ve Do, B. (2018). Affect-based model of recipients' responses to organizational change events. Academy of Management Review, 43(1), 65-86. doi:10.5465/ amr.2014.0335

Pavot, W. G., Diener, E., Colvin, C. R. ve Sandvik, E. (1991). Further validation of the satisfaction with life scale: Evidence for the cross-method convergence of well-being measures. Journal of Personality Assessment, 57, 149-161. doi:10.1207/s15327752jpa5701_17

Podsakoff, P. M. ve Organ, D. W. (1986). Self-reports in organizational research: Problems and prospects. Journal of Management, 12(4), 531-544. doi:10.1177/014920638601200408

Podsakoff, P. M., MacKenzie, S. B., Lee, J. Y. ve Podsakoff, N. P. (2003). Common method biases in behavioral research: A critical review of the literature and recommended remedies. Journal of Applied Psychology, 88(5), 879-903. doi:10.1037/0021-9010.88.5.879

Rafaeli, A. ve Sutton, R. I. (1987). Expression of emotion as part of the work role. Academy of Management Review, 12(1), 23-37. doi:10.2307/257991

Ruch, W. ve Carrell, A. (1998). Trait cheerfulness and the sense of humour. Personality and Individual Differences, 24(4). 551-558. doi:10.1016/S0191-8869(97)00221-3

Russell, J. A. (1980). A circumplex model of affect. Journal of Personality and Social Psychology, 39, 1161-1178. doi:10.1037/h0077714

Sabuncuoğlu, E. T. (2008). Rol çatışmasının ve rol belirsizliğinin tükenmişlik ve iş doyumu üzerindeki etkilerinin incelenmesi. Dokuz Eylül Üniversitesi İktisadi ve İdari Bilimler Fakültesi Dergisi, 23(1), $35-49$.

Scanlan, J. N. ve Still, M. (2019). Relationships between burnout, turnover intention, job satisfaction, job demands and job resources for mental health personnel in an Australian mental health service. BMC Health Services Research, 19(62), 1-11. doi:10.1186/s12913-018-3841-z

Schaufeli, W. B. ve Bakker A. B. (2004). Job demands, job resources, and their relationship with burnout and engagement: A multi-sample study. Journal of Organizational Behavior, 25, 293-315. doi:10.1002/job.248 
Smith, W. J., Harrington, K. V. ve Neck, C. P. (2000). Resolving conflict with humor in a diversity context. Journal of Managerial Psychology, 15(6) 606- 621. doi:10.1108/02683940010346743

Soper, D. S. (2019). Significance of the difference between two slopes calculator [Yazılım]. Erişim adresi: http://www.danielsoper.com/statcalc

Taştan, S. B. (2014). The theoretical implications of job demands-resources model: A research study on the relations of job demands, supervisor support and job autonomy with work engagement. Atatürk Üniversitesi İktisadi ve İdari Bilimler Dergisi, 28(4), 149-192.

Turgut, T. (2011). Çalışmaya tutkunluk: İş yükü, esnek çalışma saatleri, yönetici desteği ve iş-aile çatışması ile ilişkileri. Atatürk Üniversitesi İktisadi ve İdari Bilimler Dergisi, 25(3-4), 155-179.

Van Katwyk, P. T., Fox, S., Spector, P. E. ve Kelloway, E. K. (2000). Using the Job-Related Affective Well-Being Scale (JAWS) to investigate affective responses to work stressors. Journal of Occupational Health Psychology, 5(2), 219-230. doi:10.1037/1076-8998.5.2.219

Vandenberghe, C., Panaccio, A., Bentein, K., Mignonac, K. ve Roussel, P. (2011). Assessing longitudinal change of and dynamic relationships among role stressors, job attitudes, turnover intention, and well-being in neophyte newcomers. Journal of Organizational Behavior, 32, 652-671. doi:doi. org/10.1002/job.732

Warr, P., Bindl, U. K., Parker, S. K. ve Inceoglu, I. (2014). Fourquadrant investigation of job-related affects and behaviours. European Journal of Work and Organizational Psychology, 23(3), 342-363. doi:10.1080/1359432X.2012.744449

Webster, J. R., Beehr, T. A. ve Love, K. (2011). Extending the challenge-hindrance model of occupational stress: The role of appraisal. Journal of Vocational Behavior, 79, 505-516. doi:10.1016/j. jvb.2011.02.001

Weiss, H. M. ve Cropanzano, R. (1996). Affective Events Theory: A theoretical discussion of the structure, causes and consequences of affective experiences at work. Research in Organizational Behavior, 18, 1-74.

Xanthopoulou, D., Bakker, A.B., Demerouti, E. ve Schaufeli, W.B. (2007). The role of personal resources in the job demands-resources model. International Journal of Stress Management, 14, 121-141. doi:10.1037/1072-5245.14.2.121 
